\title{
Carbon isotope discrimination and differential drought tolerance in eucalypt clones
}

\author{
Discriminação isotópica de carbono e tolerância \\ diferencial de clones de eucalipto à seca
}

\author{
Flancer Novais Nunes ${ }^{1}$, Nairam Félix Barros ${ }^{2}$, Roberto Ferrera de Novais ${ }^{2}$, \\ Ivo Ribeiro da Silva ${ }^{2}$ e José Luiz Stape ${ }^{3}$
}

\begin{abstract}
Resumo
Uma estratégia utilizada para superar a limitação por água é o uso de materiais genéticos tolerantes à seca, com maior eficiência de utilização da água (EUA). A EUA está associada à discriminação isotópica do ${ }^{13} \mathrm{C}\left(\delta^{13} \mathrm{C}\right)$, que pode refletir resposta integrada das árvores ao estresse hídrico durante seu ciclo de vida. $\mathrm{O}$ objetivo desse trabalho foi verificar a relação entre $\delta^{13} \mathrm{C}$ e a tolerância ao déficit hídrico de dois clones de eucalipto, cultivados na região do cerrado. Plantios com espaçamento entre plantas de $3 \times 3 \mathrm{~m}$, de duas regiões do norte de Minas Gerais, Brasil, com quatro anos de idade, com clones de eucalipto sensível ou tolerante ao déficit hídrico, foram amostrados no fim da estação seca de 2007. Foi determinado o potencial hídrico foliar $\left(\Psi_{\text {wf }}\right)$ e $\delta^{13} \mathrm{C}$ para os dois clones, nas duas regiões. Passados dois anos, nos mesmos locais, foram determinados o índice de sobrevivência de plantas e o volume de madeira das plantas vivas e das mortas, em parcelas com espaçamento $3 \times 3 \mathrm{~m}$ (espaçamento original), $3 \times 4$ e $4 \times 6 \mathrm{~m}$ em uma das regiões, e $3 \times 3,3 \times 6$ e $4 \times 6 \mathrm{~m}$ na outra região. O clone tolerante ao déficit hídrico apresentou menor $\delta^{13} \mathrm{C}(-26.3 \%$ versus $-27.4 \%$ ) e $\Psi_{\text {wf }}(-1.7 \mathrm{MPa}$ versus $-1.3 \mathrm{MPa})$, que o sensível. O clone tolerante também apresentou maior índice de sobrevivência e maior produtividade. Os resultados sugerem que o uso da $\delta^{13} \mathrm{C}$, como indicador de clones de eucalipto tolerantes ao déficit hídrico, requer melhor entendimento dos processos que controlam esta característica.
\end{abstract}

Palavras-chave: déficit hídrico, Eucalyptus urophylla, produtividade florestal.

\begin{abstract}
Water stress is the main constraint to Eucalyptus growth in the Brazilian cerrado - a savannah type of vegetation. A strategy to overcome this constraint is the use of drought tolerance genotypes, with higher water use efficiency (WUE). WUE has been linked to isotopic discrimination of ${ }^{13} \mathrm{C}\left(\delta^{13} \mathrm{C}\right)$ which may reflect the time-integrated tree responses to drought stress during its lifespan. The relationship between $\delta^{13} \mathrm{C}$ and water stress tolerance of two contrasting Eucalyptus clones cultivated in the cerrado region was investigated. Sites with four-year-old trees of a drought-sensitive and a drought-tolerant clone, planted in a $3 \times 3 \mathrm{~m}$ spacing, in two regions of Minas Gerais State, Brazil, were sampled in 2007 in the end of an extreme dry season. Leaf water potentials $\left(\Psi_{\mathrm{wf}}\right)$ and $\delta^{13} \mathrm{C}$ were determined for both clones in both regions. Two years later, in the same location, assessments of survival rates and stem volumes of dead and living trees were performed in plots with $3 \times 3 \mathrm{~m}$ (the original spacing), $3 \times 4 \mathrm{~m}$ and $4 \times 6 \mathrm{~m}$ in one region, and $3 \times 3$ $\mathrm{m}, 3 \times 6 \mathrm{~m}$ and $4 \times 6 \mathrm{~m}$ in the other region. The drought-tolerant clone showed a slightly lower $\delta^{13} \mathrm{C}(-26.3 \%$ versus $-27.4 \%)$ and $\Psi_{\mathrm{wf}}(-1.7 \mathrm{MPa}$ versus $-1.3 \mathrm{MPa})$ than the sensitive one. The tolerant clone also had a higher survival rate and yield. The results suggest that the use of $\delta^{13} \mathrm{C}$ as an indicator of drought tolerance for Eucalypt clones requires a better understanding of the underlying processes that control its expression and how the different traits can affect its expression.
\end{abstract}

Keywords: water stress, Eucalyptus urophylla, forest productivity.

\section{INTRODUÇÃO}

The growing demand for forest products such as charcoal and fibers has led to the fast expansion of planted forests in Brazil, with more than one million hectares of new areas in the last five years (ABRAF, 2012). This expansion occurs mainly in the Cerrado, a savanna type of vegetation with

${ }^{1}$ Doctor Resarcher. Copener - Bahia Specialty Cellulose, Dr. José Tiago, s/n 48030-480 - Alagoinhas, BA, Brazil. E-mail: flancer_nunes@bahiaspeccell.com.

2PhD Professor at Department of Soil Science. UFV - Universidade Federal de Viçosa - 36570-000 - Viçosa, MG, Brazil. E.mail: nfbarros@ufv.br; rfnovais@ufv.br; ivosilva@ufv.br.

3Doctor Resarcher. Suzano Celulose e Papel. Salvador, BA, Brazil. E-mail: stape@suzano.com.br. 
low fertility soils (LOPES; COX, 1977), region which has a wet/dry rainfall regime and can have severe water restriction, limiting survival and growth. In 2007, an extreme 8 months-long dry season occurred in Minas Gerais State and extensive areas of Eucalyptus clones were devastated, while adjacent areas with other genotypes withstood the drought with only minor problems.

Water deficit is well known to be a major factor limiting the productivity of Eucalyptus, even in areas considered favorable for good growth and development of forests (STAPE, et al., 2010; GONÇALVES et al., 2014). Low water availability leads to both increased tree mortality and decreased tree growth resulting in the drop of forest productivity (CHAMBER; BORRALHO, 1997).

Different physiological processes may be involved in plant drought tolerance, such as leaf area dynamics, osmotic adjustment, root development, root/shoot ratio, and lower stomata conductance, among others. Water use efficiency (WUE); the ratio between biomass production and water transpired by trees, is influenced by vapor pressure deficit and by intrinsic water use efficiency - the ratio between stomata conductance and photosynthetic rate. Stomata closure can maintain tissue hydration but can reduce productivity because it prevents $\mathrm{CO}_{2}$ absorption. However, some genotypes may allow partial stomata opening, reducing water loss and maintaining the internal $\mathrm{CO}_{2}$ concentration, resulting in a photosynthetic rate which conduces to a greater WUE (CONDON et al., 2004).

The isotope discrimination of ${ }^{13} \mathrm{C}\left(\delta^{13} \mathrm{C}\right)$ is positively related to growth under conditions were stomata play a major role in determining the rate of carbon diffusion into the leaves (FARQUHAR et al., 1989; FLANAGAN; FARQUHAR, 2014), which is strongly coupled to measures of water availability (KEITEL et al., 2003). In $\mathrm{C}_{3}$ plants, $\delta^{13} \mathrm{C}$ is due to the lower diffusion rate of ${ }^{13} \mathrm{C}$, heavier than the ${ }^{12} \mathrm{C}$, causing discrimination of about $-4.4 \%$, and lower affinity of rubisco for ${ }^{13} \mathrm{C}$, resulting in the final discrimination of approximately - $28 \%$ o (O'LEARY, 1981). However, under conditions where the internal concentration of $\mathrm{CO}_{2}$ is reduced by the lower stomata opening, as in the warmest hours of the day; and photosynthetic rate is maintained, there is a lower discrimination of ${ }^{13} \mathrm{C}$ against to ${ }^{12} \mathrm{C}$ by rubisco. DaMatta et al. (2003), working with coffee plants, observed that tolerant clones showed lower stomata conductance and lower $\delta^{13} \mathrm{C}$, concomitant to the maintenance of higher leaf area and leaf water potential. However, physiological processes involved in adaptation to water stress of these clones are still unclear.

The establishment of the relationships between photosynthetic rate and stomata conductance with $\delta^{13} \mathrm{C}$ and WUE (FARQUHAR et al., 1989; DVORAK, 2012) may allow the use of $\delta^{13} \mathrm{C}$ as a tool for genotypes selection for drought tolerance. Moreover, ${ }^{13} \mathrm{C}$ signature might have higher heritability than other measures of WUE (McKAY et al., 2003). Field trials under more controlled conditions have proven the use of $\delta^{13} \mathrm{C}$ as a good indicator of the WUE and useful in the selection of many drought-tolerant plant genotypes (CONDON et al. 2004; EASLON et al. 2014). Additionally, $\delta^{13} \mathrm{C}$ provides an integrated measure of plants' physiological properties during their cycle, especially of the photosynthetic rate and stomata conductance in relation to environmental conditions (ANDERSON et al., 1996). Thus, the objective of this study was to evaluate the $\delta^{13} \mathrm{C}$, survival and stem volume of two contrasting Eucalyptus clones regarding their sensitivity to drought in two typical tropical water stress regions of Brazil.

\section{MATERIAL E MÉTODOS}

\section{Sites and treatments}

This study used four-year-old eucalypt plantations, located in Brasília de Minas (16 $16^{\circ} 23^{\prime \prime}$ $\mathrm{S}$ and $\left.44^{\circ} 26^{\prime} 00^{\prime \prime} \mathrm{W}\right)$ and Bocaiúva ( $17^{\circ} 06^{\prime} 28^{\prime \prime} \mathrm{S}$ and $\left.43^{\circ} 48^{\prime} 54^{\prime \prime} \mathrm{W}\right)$ municipalities in Minas Gerais State, Brazil. In Brasilia de Minas eucalypt clones were planted on a sandy clay loam RedYellow Latossol, while in Bocaiuva on a clay loam Red Latossol. Clones are hybrids of Eucalyptus urophylla but presented differential tolerance to the water deficit that occurred during the 2007 dry season. The assessments were carried out in spacing trial plots planted at the end of 2003 and the plants showed no major water stress during the first three years. The dry season regularly goes from April to September, but in 2007 it went from April to November which was the longest drought in the recent years. Rainfall during this period was basically none (Figure 1). One plot of droughtsensitive (Clone 042) and another of drought-tolerant (Clone I-144) clone were selected based on visual symptoms (dried branches and leaves from the base to the top), at the end of the dry season 
in experimental areas of Plantar Reflorestamentos Company (Figure 2). In these experimental trials, spacing of $3 \times 3 \mathrm{~m}, 3 \times 4 \mathrm{~m}$ and $4 \times 6 \mathrm{~m}\left(9,12\right.$ and $24 \mathrm{~m}^{2}$ per plant) were used in Brasília de Minas region, while in Bocaiúva region spacing were $3 \times 3 \mathrm{~m}, 3 \times 6 \mathrm{~m}$ and $4 \times 6 \mathrm{~m}\left(9,18\right.$ and $24 \mathrm{~m}^{2}$ per tree). We selected the most common spacing used in Brazil $-3 \times 3 \mathrm{~m}$, for the measurements and ${ }^{13} \mathrm{C}$ sampling process.

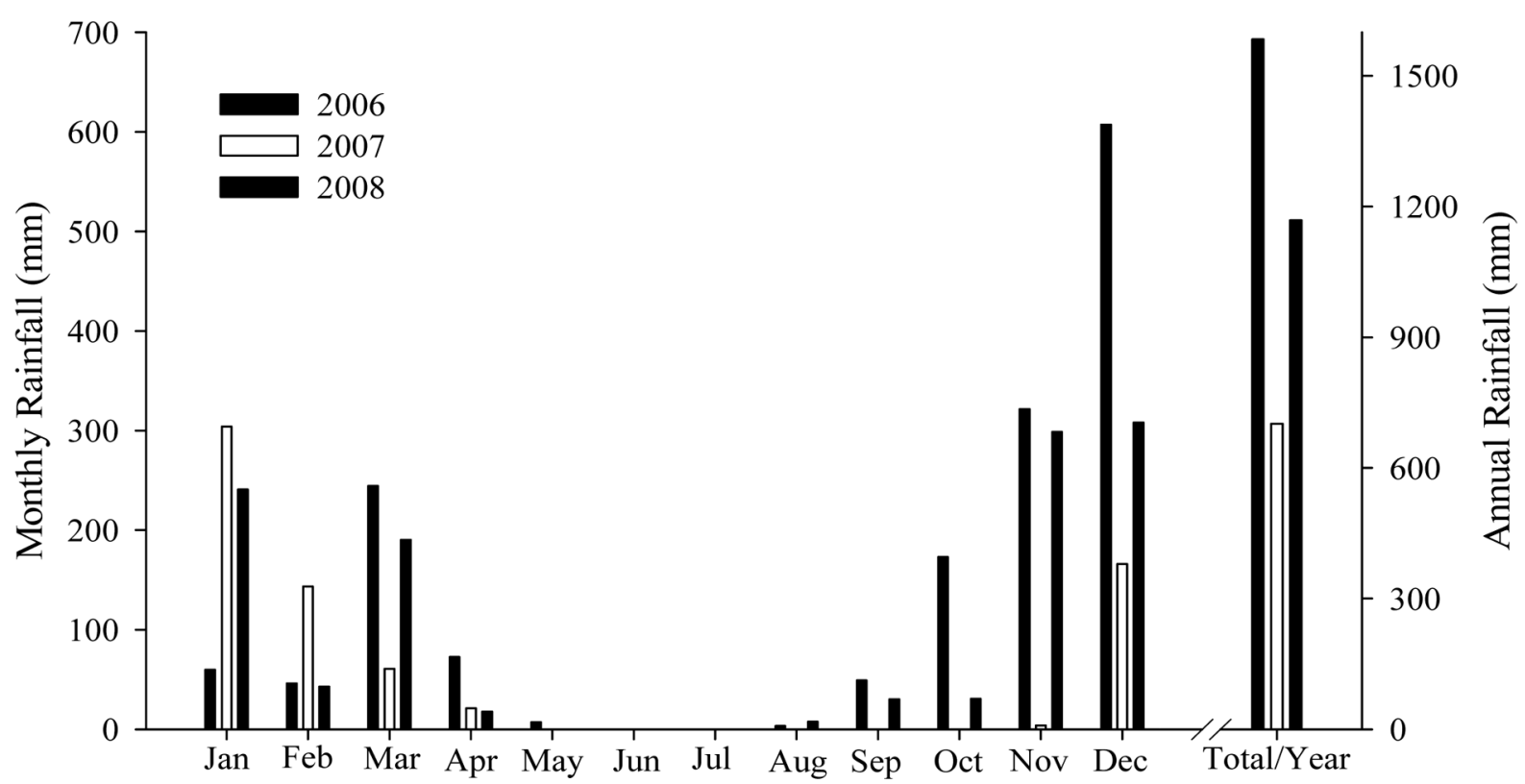

Figura 1. Average rainfall for the region of Brasília de Minas and Bocaiúva (MG) for the years 2006, 2007 and 2008. Figure 1. Precipitação pluvial média para a região de Brasília de Minas e Bocaiúva (MG) para os anos 2006, 2007 e 2008.

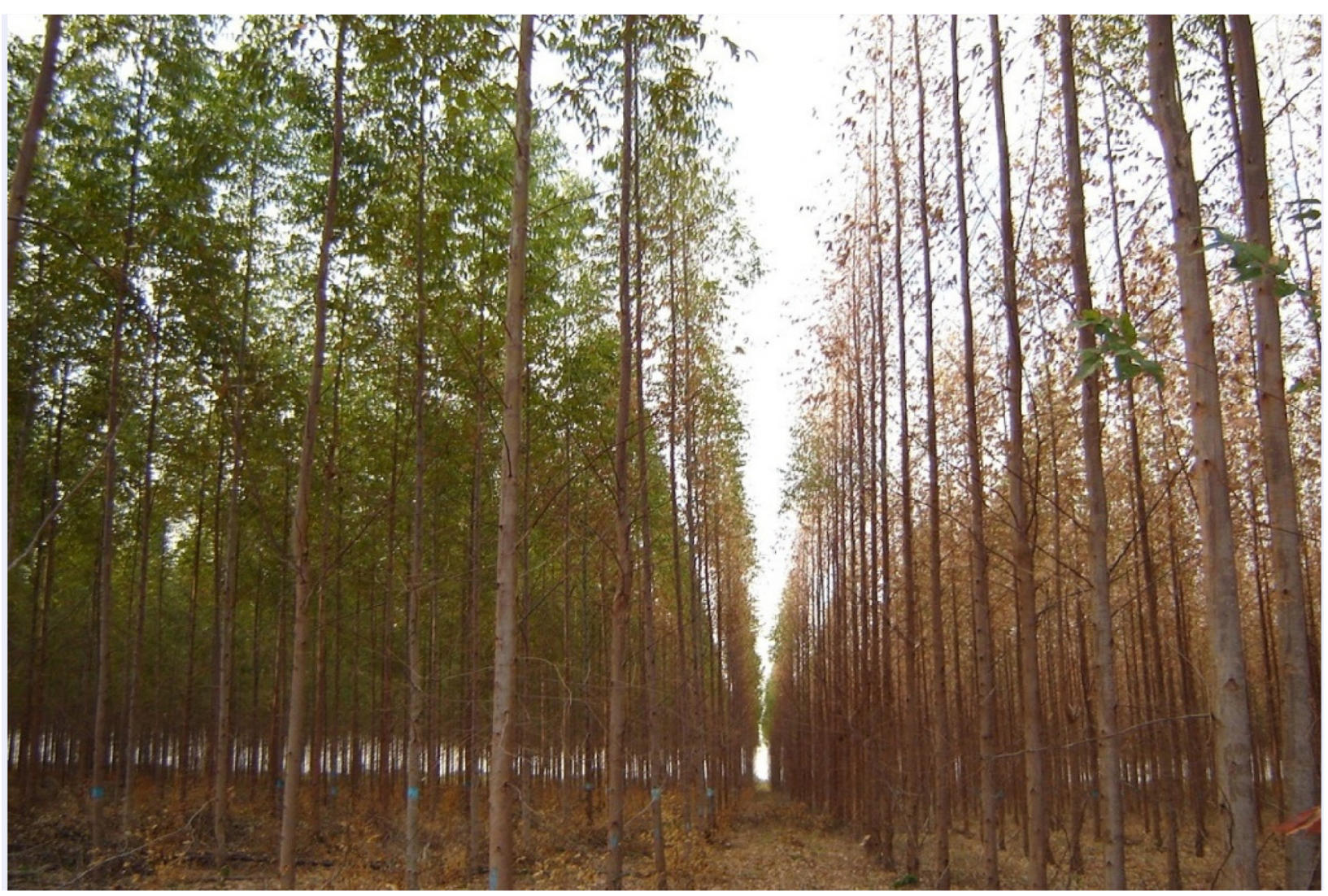

Figura 2. Eucalypt plots in the experimental area in Brasilia de Minas. Picture taken on the border between plots with sensitive (at the right side) and tolerant (at the left side) clone.

Figure 2. Parcelas plantadas com eucalipto na área experimental de Brasília de Minas. Imagem tomada na divisa entre parcelas com o clone sensível (à direita) e tolerante ao déficit hídrico (à esquerda). 
In each plot, four average trees without visual symptoms of water deficit were selected, resulting in four replications. The selected trees were cut down in the period between 12:00 and 14:00 $\mathrm{h}$, and the fourth leaves of apical branches were collected in four branches of the middle third of each tree for determination of water potential using a Scholander-type pressure chamber (model 3005, Soil Moisture Equipment). The leaf water potential of each tree was composed by an average of four readings. Wood sampling consisted of one debarked slice taken at $1.4 \mathrm{~m}$ above ground, and leaf (fourth fully expanded leaf) were collected from each tree. Wood from the sliced edge and leaf samples were dried in a forced draft oven at $70{ }^{\circ} \mathrm{C}$ for $72 \mathrm{~h}$ to a constant weight and ground for ${ }^{13} \mathrm{C}$ determination.

The total stem volume (sum of living and dead trees); volume of living trees and survival rate for each planting space, were determined evaluating 25 central plants per plot, in March 2009, i.e., when trees were 6.4 years old. The survival rate was calculated as the percentage of living trees in relation to all trees (living plus dead) of each plot.

\section{Carbon isotope discrimination and statistical analysis}

The carbon isotope composition was determined using an isotopic ratio mass spectrometer (ANCA-GLS Sercom, Crewe, UK) at the Stable Isotope Laboratory of the Federal University of Viçosa. Stable carbon isotope ratios were calculated as $\delta^{13} \mathrm{C}=R_{\text {sample }} / R_{\text {standard }}-1$, where $R$ is the molar ratio of heavy and light isotope $\left({ }^{13} \mathrm{C} /{ }^{12} \mathrm{C}\right)$. The $\delta^{13} \mathrm{C}$ values were expressed in per thousand and relative to the international standard, Pee Dee Belemnite limestone, (CRAIG, 1957).

Data of leaf water potential and $\delta^{13} \mathrm{C}$ and were analyzed according to a completely randomized design; and data of survival rate and stem volume by living and dead trees were analyzed according a randomized block design. The effects of control variables were subjected to variance analysis and, when necessary, submitted to the Tukey test at 5\%.

\section{RESULTADOS E DISCUSSÃO}

A lower value of leaf water potential $\left(\Psi_{\mathrm{wf}}\right)$ was found in the water deficit tolerant clone (-2.0 MPa), in Brasília de Minas, when compared with values obtained in the same clone in Bocaiúva (-1.4 MPa, Table 1), suggesting that in Bocaiúva the water stress was lower during the sampling time. This may have been due to the lower atmospheric demand - vapor pressure deficit, for example - because the soil water potential of the 0 - $1.6 \mathrm{~m}$ layer was similar at both locations and averaged -1.68 and -1.66 MPa for Brasília de Minas and Bocaiúva, respectively. The drought-tolerant clone showed smaller values of $\Psi_{w f}$ with the largest differences observed in Brasília de Minas region (Table 1). This result, smaller $\Psi_{w f}$ for the tolerant clone, was not expected since the mechanisms that generally promote greater tolerance of plants to water deficit, as lower stomata conductance, are related to the maintenance of higher $\Psi_{\text {wf }}$ values (DaMATTA et al., 2003).

Table 1. Isotopic discrimination of ${ }^{13} \mathrm{C}\left(\delta^{13} \mathrm{C}\right)$ in leaves and wood samples of drought-sensitive and drought-tolerant eucalypt clones collected in four-year-old plantations in Brasília de Minas and Bocaiuva.

Tabela 1. Discriminação isotópica do ${ }^{13} \mathrm{C}\left(\delta^{13} \mathrm{C}\right)$ em amostras de folha e lenho de clones sensível e tolerante ao déficit hídrico coletados em plantios com quatro anos de idade em Brasília de Minas e em Bocaiúva.

\begin{tabular}{|c|c|c|c|}
\hline \multirow[t]{2}{*}{ Clone } & \multirow{2}{*}{$\begin{array}{c}\Psi_{\mathrm{w}} \\
\mathrm{MPa}\end{array}$} & \multicolumn{2}{|c|}{$\delta^{13} \mathrm{C}(\%)$} \\
\hline & & Leaf & Wood \\
\hline & \multicolumn{3}{|c|}{ Brasília de Minas } \\
\hline Tolerant & $-2,00 \mathrm{Aa}$ & $-26,16 \mathrm{Aa}$ & $-26,27 A a$ \\
\hline \multirow[t]{2}{*}{ Sensitive } & $-1,40 \mathrm{Ba}$ & $-27,27 \mathrm{Ba}$ & $-27,36 \mathrm{Ba}$ \\
\hline & \multicolumn{3}{|c|}{ Bocaiúva } \\
\hline Tolerant & $-1,40 A b$ & $-26,28 \mathrm{Aa}$ & $-26,86 A a$ \\
\hline Sensitive & $-1,20 \mathrm{Aa}$ & $-27,53 \mathrm{Ba}$ & $-27,33 \mathrm{Aa}$ \\
\hline
\end{tabular}

Means followed by the same capital letter within each locality (comparing the clones effect), and by the same lower case within each clone (comparing the locality effect) did not differ by the $F$ test at $5 \%$.

Médias seguidas pela mesma letra maiúscula, dentro de cada localidade (comparando o efeito dos clones), e pela mesma letra minúscula, dentro de cada clone (comparando o feito da localidade), não diferem entre si pelo tese $\mathrm{F}$ a $5 \%$. 
The lowest $\Psi_{w f}$ observed in the drought-tolerant clone, in Brasília de Minas, was associated with lower $\delta^{13} \mathrm{C}$ (Table 1 ). The $\delta^{13} \mathrm{C}$ is strongly coupled with physiological status of fully expanded leaves and sensitive indicator of water availability in E. globulus seedlings (MERCHANT al., 2010). Similar results were observed by Yin et al. (2009), who found that conditions which favored better transpiration control of plants grown under limited water conditions contributed to lower $\delta^{13} \mathrm{C}$ and lower water content in the leaves of two tree species, Populus cathayana and P. przewalskii. These results contrast the woody plant literature (DaMATTA et al., 2003; DUCREY et al., 2008), which indicates that low $\Psi_{\text {wf }}$ leads to lower photosynthetic rates and consequently higher isotope discrimination, i.e. more negative values of $\delta^{13} \mathrm{C}$.

There were no significant differences between the $\delta^{13} \mathrm{C}$ values of leaf and wood samples (Table 1), pointing that the ${ }^{13} \mathrm{C}$ signature in leaf or wood samples can be potentially used to assess the water stress. Plants with improved stomata control and greater water use efficiency (WUE) are generally better adapted to conditions of low water availability (BATTIPAGLIA et al., 2014). Hence, a positive correlation between WUE and $\delta^{13} \mathrm{C}$ has been observed (LI, 2000, DUAN et al., 2009). The drought-tolerant clone showed lower $\delta^{13} \mathrm{C}$ values, i.e. less discrimination of ${ }^{13} \mathrm{C}$ in leaf and wood samples (Table 1). Variations in $\delta^{13} \mathrm{C}$ may result from changes in the carboxylation rate and stomata conductance, or both processes (FARQUHAR et al., 1989). Assuming that the photosynthetic rate in the drought-sensitive and drought-tolerant clone are similar $\left(13,8 \mu \mathrm{mol} \mathrm{m}{ }^{-2} \mathrm{~s}^{-1}\right.$, in five-monthsold seedlings growing in nutrient solution, data not shown), the lower $\delta^{13} \mathrm{C}$ in the tolerant clone indicates a better stomata control, maintaining the photosynthetic rate, even with lower stomata conductance. This indicates that the tolerant clone has a strategy to use water more conservatively, as suggested by Li (2000).

The tolerant clone under water deficit conditions showed a higher survival rate (Figure 3 ) associated with lower $\delta^{13} \mathrm{C}$ (Table 1 ). In the Brasília de Minas municipality county, the tolerant clone in $3 \times 3 \mathrm{~m}$ spacing, presented $\delta^{13} \mathrm{C}$ of $-26.28 \%$ and survival rate of $82.3 \%$, whereas the sensitive clone showed $-27.34 \%$ and $16.8 \%$, respectively. Levanic et al. (2010) also reported lower $\delta^{13} \mathrm{C}$ associated to higher survival rate. Although the values are slightly distinct, these results support the hypothesis that tolerant clones have lower stomata conductance associated with the maintenance of photosynthetic rate, contributing to lower isotope discrimination. Pita et al. (2001) reported different results from these findings. They found a positive correlation between $\delta^{13} \mathrm{C}$ and tree survival, suggesting that the $\mathrm{C}$ isotopic composition would not be a good indicator of the trees adaptability to water deficit conditions. In their work, clones of different drought tolerance were planted in rows, enabling competition among different clones. Thus, $\delta^{13} \mathrm{C}$ records and survival were influenced by the presence of neighbors competing for water during their lifespan - at least seven years in the work of Pita and partners.

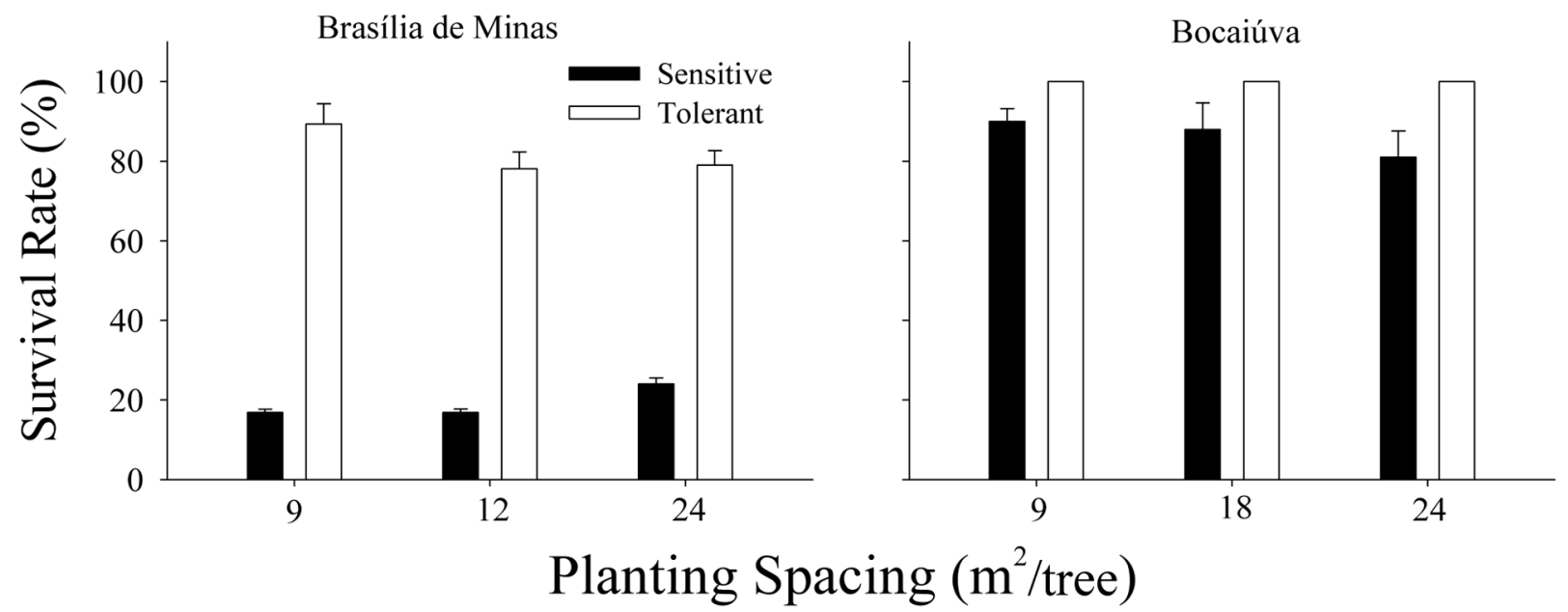

Figura 3. Survival rate of drought-sensitive and drought-tolerant eucalypt clones as affected by spacing, in 6,4-year-old eucalypt plantation in Brasília de Minas and Bocaiúva. Each bar represents the average of four replicates with their standard error.

Figure 3. Índice de sobrevivência dos clones de eucalipto sensível e tolerante ao déficit hídrico em razão do espaçamento, em florestas com 6,4 anos de idade, em Brasília de Minas e em Bocaiúva. Cada barra representa média de quatro repetições com respectivo erro padrão. 
The survival rate was higher in Bocaiuva than in Brasília de Minas (Figure 3). This is explained by the lower water deficit in the former location, which varies between 200 and $250 \mathrm{~mm} \mathrm{year}^{-1}$, as compared with 300 to $350 \mathrm{~mm}$ in Brasília de Minas. Despite of that, there was no difference in ${ }^{13} \mathrm{C}$ between sites, regardless of genetic material (Table 1), suggesting that this trait is little affected by environmental conditions. Lack of genetic variation for carbon isotope composition has been found in Pinus sp. (ROWELL et al. 2008; ARANDA et al., 2010). In this work, both clones - droughtsensitive or drought-tolerant - were selected under limiting water availability environment. Aranda et al. (2010), working with four Pinus pinaster populations, reported low response of isotope carbon composition to drought treatment in seedlings originated from dry environment populations.

However, the slight significant difference for the $\delta^{13} \mathrm{C}$ between the drought-sensitive and droughttolerant clones may indicate that the $\delta^{13} \mathrm{C}$ can be used as a tool for selecting genotypes more suitable for water limiting environments if we better understand the processes that control this outcome. Supporting these finds, Hubbard et al. (2010) showed insignificant variations in transpiration, canopy conductance, wood growth and WUE, between rain fed and irrigated Eucalyptus plantations. Bartholomé et al. (2015) also suggested that $\delta^{13} \mathrm{C}$ and the WUE are characteristics that suffer low environmental interference.

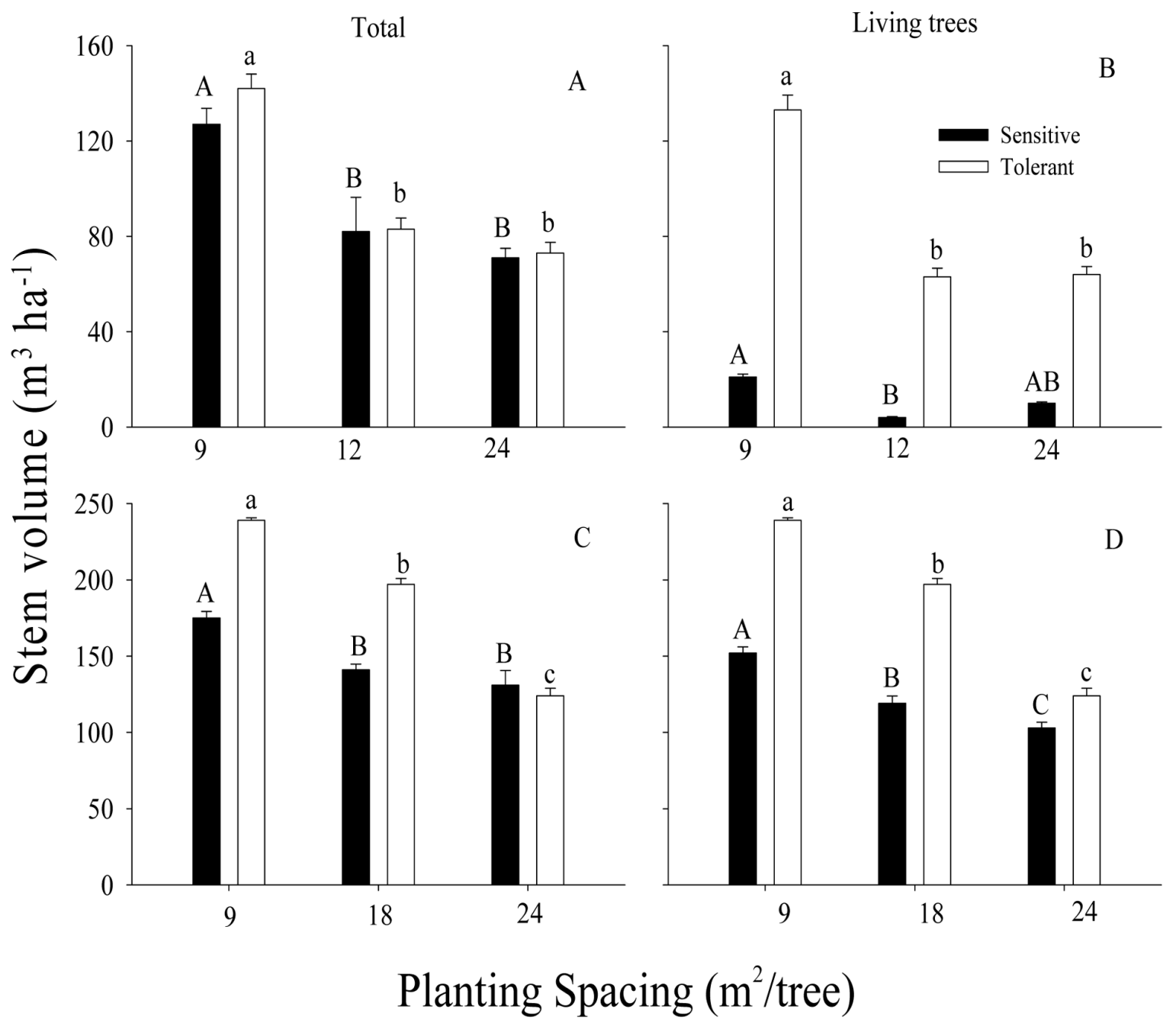

Means followed by the same upper case (for sensitive clone), or by the same lower case (for tolerant clone), comparing the spacing effect between plants, do not differ by Tukey test at $5 \%$.

Médias seguidas pela mesma letra maiúscula (para clone sensível), ou pela mesma letra minúscula (para o clone tolerante), comparando o efeito de espaçamento entre plantas, não diferem entre si pelo teste de Tukey a $5 \%$.

Figura 4. Total stem volume (stem of live and dead plants), and stem volume of living plants of 6.4-year-old drought-sensitive and drought-tolerant eucalypt clones as affected by spacing planting in Brasília de Minas (A and $B$ ) and Bocaiúva ( $C$ and $D)$. Each bar represents the mean of four replicates with their standard error.

igure 4. Volume total de tronco (soma da produção das plantas vivas e mortas), e produtividade por plantas vivas aos 6,4 anos de idade, para os clones de eucalipto sensível e tolerante ao estresse hídrico em razão do espaçamento de plantio em Brasília de Minas ( $A$ e $B$ ) e em Bocaiúva ( $C$ e $D)$. Cada barra representa média de quatro repetições com respectivo erro padrão. 
The two clones showed lower stem volume in conditions of wider tree spacing in Brasília de Minas (Figure 4), especially for the drought-sensitive clone, which showed a drastic reduction in survival as a consequence of the severe dry season that preceded sampling (Figures 3 and 4). Higher survival rate was expected under wider spacing conditions because lowering tree density would favor a lower water competition among trees and, consequently, higher water availability, higher survival and potentially higher tree volume. We observed a higher wood volume and lower $\delta^{13} \mathrm{C}$ in both regions, for the drought-tolerant clone (Figure 4, Table 1). In Bocaiúva, for example, the tolerant clone volume was $191 \mathrm{~m}^{3} \mathrm{ha}^{-1}$ and $\delta^{13} \mathrm{C}$ in the leaf of $-26.28 \%$, while for the sensitive the volume was $141 \mathrm{~m}^{3} \mathrm{ha}^{-1}$ and $\delta^{13} \mathrm{C}$ of $-27.53 \%$. The positive correlation between the values of $\delta^{13} \mathrm{C}$ and productivity has also been reported in other studies (SARRIS et al., 2013) and may be due to a lower stomata conductance associated with the maintenance of the photosynthetic rate by the tolerant clone (DUCREY et al., 2008). This suggests that this clone has mechanisms that provide a greater transpiration efficiency and hence higher productivity than the drought-sensitive one when growing in environments under severe water deficit.

\section{CONCLUSÕES}

The results reported in this work suggest that $\delta^{13} \mathrm{C}$ can be potentially used as an indicator of drought tolerance in eucalypt clones. However, the variability of responses across species, clones and sites is unknown and must be better addressed and investigated. There are several ways that a tree can avoid water stress, and their effect on the $\mathrm{C}$ discrimination should be clarified. Thus, for forest breeders to consider using $\delta^{13} \mathrm{C}$ on their programs; benefits would have to be shown in other field experiments using a wide range of genetic material and sites.

\section{AGRADECIMENTOS}

F.N. Nunes was sponsored by CNPq and the DPS/Universidade Federal de Viçosa grant 140008/2007-1. The plantations were established and managed by Plantar S/A Reflorestamentos, and site access and provision growth data from permanent sampling plots is gratefully acknowledged. The authors thank these companies technical team who helped on samples collection and field measurements. I.R. Silva, N.F. Barros and R.F. Novais acknowledge the financial support provided by CNPq for the development of this study.

\section{REFERÊNCIAS BIBLIOGRÁFICAS}

ABRAF - BRAZILIAN ASSOCIATION OF FOREST PLANTATION PRODUCERS. Yearbook Statistical ABRAF 2013: base year 2012. Brasília, 2013. 148 p.

ANDERSON, J. E.; WILLIANS, J.; KRIEDEMANN, P. E.; AUSTIN, M. P.; FARQUHAR, G. D. Correlations between carbon isotope discrimination and climate of native habitats for diverse eucalypt taxa growing in a common garden. Australian Journal of Plant Physiology, Melbourne, v. 23, p. 311-320, 1996.

ARANDA, I.; ALÍA, R.; ORTEGA, U.; DANTAS, A. K.; MAJADA, J. Intra-specific variability in biomass partitionig and carbon isotopic discrimination under moderate drought stress in seedlings from four Pinus pinaster populations. Tree Genetics and Genomes, v. 6, n. 2, p. 169-178, 2010.

BARTHOLOMÉ, J.; MABIALA, A.; SAVELLI, B.; BERT, D.; BRENDEL, O.; PLOMION, C.; GION, J. Genetic architecture of carbon isotope composition and growth inEucalyptus across multiple environments. New Phytologist, Oxford, v. 206, n. 4, p. 1437-1449, 2015.

BATTIPAGLIA, G.; DE MICCO, V.; BRAND, W. A.; SAURER, M.; ARONNE, G.; LINKE, P.; CHERUBINI, P. Drought impact on water use efficiency and intra-annualdensity fluctuations in Erica arborea on Elba (Italy). Plant Cell and Environment, Oxford, v. 37, n. 2, p. 382-391, 2014. 
Nunes et al. - Carbon isotope discrimination and differential drought tolerance in eucalypt clones

CHAMBERS, P. G. S.; BORRALHO, N. M. G. Importance of survival in short-rotation tree breeding programs. Canadian Journal of Forest Research, Ottawa, v. 27, n. 6, p. 911-917, 1997.

CONDON, A. G.; RICHARDS, R. A.; REBETZKE, G. J.; FARGUHAR, G. D. Breeding for high water use efficiency. Journal of Experimental Botany, Oxford, v. 55, n. 407, p. 2447-2460, 2004.

CRAIG, H. Isotope standards for carbon and oxygen and correction factors for mass-spectrometric analysis of carbon dioxide. Geochimica et Cosmochimica Acta, v. 12, n. 1-2, p. 133-149, 1957.

DAMATTA, F. M.; CHAVES, A. R. M.; PINHEIRO, H. A.; DUACTTI, C.; LOUREIRO, M. E. Drought tolerance of two field-grown clones of Coffea canephora. Plant Science, Amsterdam, v. 164, n. 1, p. 111-117, 2003.

DUAN, B.; LI, Y.; ZHANG, X.; KORPELAINEN, H.; LI, C. Water deficit affects mesophyll limitations of leaves more strongly in sun than in shade in two Pice asperata populations. Tree Physiology, Victoria, v. 29, n. 12, p. 1551-1561, 2009.

DUCREY, M.; HUC, H.; LADJAL, M.; GUEHL, J. M. Variability in growth, carbon isotope composition, leaf gas exchange and hydraulic traits in the eastern Mediterranean cedars Cedrus libani and C. brevifolia. Tree Physiology, Victoria, v. 28, n. 5, p. 689-701, 2008.

DVORAK, W. S. Water use in plantations of eucalypts and pines: a discussion paper from a tree breeding perspective. International Forestry Review, Bicester, v. 14, n. 1, p. 110-119, 2012.

EASLON, H. M.; NEMALI, K. S.; RICHARDS, J. H.; HANSON, D. T.; JUENGER, T. E.; McKAY, J. K. The physiological basis for genetic variation in water use efficiency and carbon isotope composition in Arabidopsis thaliana. Photosynthesis Research, v. 119, n. 1-2, p. 119-129, 2014.

FARQUHAR, G. D.; EHLERINGER, J. R.; HUBICK, K. T. Carbon isotope discrimination and photosynthesis. Annual Review of Plant Physiology and Plant Molcular Biology, Palo Alto, v. 40, p. 503-537, 1989.

FLANAGAN, L.; FARQUHAR, G. D. Variation in the carbon and oxygen isotope composition of plant biomass and its relationship to water-use efficiency at the leaf- and ecosystem-scales in a northern Great Plains grassland. Plant Cell and Environment, Oxford, v. 37, n. 2, p. 425-438, 2014.

GONÇALVES, J. L. M.; ALVARES, C. A.; BEHLING, M.; ALVES, J. M.; PIZZI, G. T., ANGELI, A. Produtividade de plantações de eucalipto manejadas nos sistemas de alto fuste e talhadia, em função de fatores edafoclimáticos. Scientia Forestalis, Piracicaba, v. 42, n. 103, p. 411-419, 2014.

HUBBARD, R. M.; STAPE, J. L.; RYAN, M. G.; ALMEIDA, A. C.; ROJAS, A. Effects of irrigation on water use and water use efficiency in two fast growing Eucalyptus plantations. Forest Ecology and Management, Amsterdam, v. 259, p. 1714-1721, 2010.

KEITEL, C.; ADAMS, M. A.; HOLST, T.; MATZARAKIS, A.; MAYER, H.; RENNENBERG, H.; GESSLER, A. Carbon and oxygen isotope composition of organic compounds in the phloem sap provides a short-term measure for stomatal conductance of European beech (Fagus sylvatica L.). Plant Cell and Environment, Oxford, v. 26, n. 7, p. $1157-1168,2003$.

LEVANIC, T.; CATER, M.; MCDOWELL, N. G. Associations between growth, wood anatomy, carbon isotope discrimination and mortality in a Quercus robur forest. Tree Physiology, Victoria, v. 31, n. 3, p. 298-308, 2010.

LI, C. Population differences in water-use efficiency of Eucalyptus microtheca seedlings under different watering regimes. Physiologia Plantarum, Kopenhagen, v. 108, n. 2, p. 134-139, 2000.

LOPES, A. J.; COX, F. R. A survey of the fertility status of surface soils under cerrado vegetation of Brazil. Soil Science Society of America Journal, Madison, v. 41, n. 4, p. 752-757, 1977. 
MCKAY, J. K.; RICHARDS, J. H.; MITCHELL-OLDS, T. Genetics of drought adaptation in Arabidopsis thaliana: I. Pleiotropy contributes to genetic correlations among ecological traits. Molecular Ecology, Oxford, v. 12, n. 5, p. 1137-1151, 2003.

MERCHANT, A.; PEUKE, A. D.; KEITEL, C.; MACFARLANE, C.; WARREN, C. R.; ADAMS, M. A. Phloem sap and leaf 13C, carbohydrates, and amino acid concentrations in Eucalyptus globulus change systematically according to flooding and water deficit treatment. Journal of Experimental Botany, Oxford, v. 61, n. 6, p. 1785-1793, 2010 .

O'LEARY, M. H. Carbon isotope fractionation in plants. Phytochemistry, v. 20, n. 4, p. 553-567, 1981.

PITA, P.; SORIA, F.; CANAS, I.; TOVAL, G.; PARDOS, J. A. Carbon isotope discrimination and its relationship to drought resistance under field conditions in genotypes of Eucalyptus globulus Labill. Forest Ecology Management, Amsterdam, v. 141, n. 3, p. 211-221, 2001.

ROWELL, D. M.; ADES, P. K.; TAUZ, M.; ARNDT, S. K.; ADASMS, M. A. Lack of genetic variation in tree ring $\delta^{13} \mathrm{C}$ suggests a uniform stomatally-driven reponse to drought stress across Pinus radiata genotypes. Tree Physiology, Victoria, v. 29, n. 2, p. 191-198, 2008.

SARRIS, D.; SIEGWOLF, R.; KÖRNER, C. Inter and Intra-annual stable carbon and oxygen isotope signals in response to drought in Mediterranean pines. Agricultural and Forest Meteorology, Amsterdam, v. 168, p. 59-68, 2013.

STAPE, J. L.; BINKLEY, D.; RYAN, M. G.; FONSECA, S.; LOOS, R. A.; TAKAHASHI, E. N.; SILVA, C. R.; SILVA, S. R.; HAKAMADA, R. E.; FERREIRA, J. M. A.; LIMA, A. M. N; GAVA, J. L.; LEITE, F. P.; ANDRADE, H. B.; ALVES, J. M.; SILVA, G. G. C.; AZEVEDO, M.R. The Brazil eucalyptus potential productivity project: influence of water, nutrients and stand uniformity on wood production. Forest Ecology and Management, Amsterdam, v. 259, n. 9, p. 1684-1694, 2010.

YIN, C.; PANG, X.; CHEN, K. The effects of water, nutrient availability and their interaction on the growth, morphology and physiology of two poplar species. Environmental and Experimental Botany, Oxford, v. 67, n. 1, p. 196-203, 2009.

Recebido em 03/05/2015

Aceito para publicação em 27/04/2016

Sci. For., Piracicaba, v. 44, n. 112, p. 895-903, dez. 2016

DOI: dx.doi.org/10.18671/scifor.v44n112.11 
